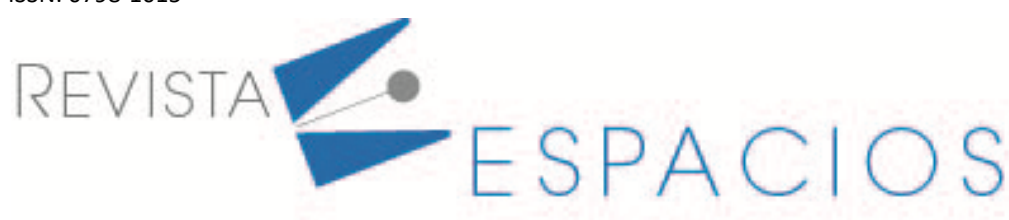

Vol. 41 (45) $2020 \cdot$ Art. 5

Recibido/Received: 04/06/2020 • Aprobado/Approved: 16/11/2020 • Publicado/Published: 26/11/2020

\title{
Key interest rate in optimal monetary policy in Ukraine
}

\section{Tasa de interés clave en la política monetaria óptima en Ucrania}

\author{
BONDARCHUK, Vitalii ${ }^{1}$ \\ BOGOYAVLENSKA, Yuliya ${ }^{2}$ \\ KALENCHUK, Lyudmyla ${ }^{3}$ \\ SHYMANSKA, Kateryna ${ }^{4}$
}

\begin{abstract}
En el documento, se ha presentado el examen empírico del uso de la regla de Taylor en el caso de Ucrania. Los resultados obtenidos han demostrado que la influencia más significativa sobre la tasa de interés la hace la tasa de inflación y la tasa de interés del período anterior. Se encontró que un cambio de $1 \%$ en los precios de consumo y la tasa de interés en el período anterior aumenta la tasa de interés en un 1,28 y $0,71 \%$, respectivamente. Por otro lado, un cambio del $1 \%$ en la brecha del PIB provoca solo una variación del $0,04 \%$ en la tasa de interés. Los resultados obtenidos han demostrado que el cambio del $1 \%$ de la brecha de inflación provocó que el Banco Nacional de Ucrania aumentará la tasa de interés en un 0,8\%.

key words: Monetary Policy, Taylor Rule, Modified Taylor Rule, Inflation Targeting

Resumen

(En el documento, se había presentado el examen empírico del uso de las reglas de Taylor en el caso de Ucrania. Los resultados obtenidos habían mostrado que la influencia más significativa en la tasa de interés hace que la tasa de inflación y la tasa de interés en el período anterior. Se había constatado que el cambio del $1 \%$ de los precios de consumo y la tasa de interés en el período anterior aumenta la tasa de interés en un 1,28 y un $0,71 \%$, respectivamente. En cambio, el cambio del $1 \%$ en la brecha del PIB causa sólo un cambio del $0,04 \%$ en la tasa de interés. Los resultados obtenidos habían mostrado que el cambio del $1 \%$ de la brecha inflacionaria provocaba que el Banco Nacional de Ucrania aumentara la tasa de interés en un $0,8 \%$.

Palabras clave: Política monetaria, regla de Taylor, regla de Taylor modificada, objetivos de inflación
\end{abstract}

\section{Introduction}

Stability of national currency is one of the main factors of sustainable economic growth in emerging economies. Ukraine has launched national currency in 1996 and since that moment National Bank of Ukraine is in charge of monetary policy development and conducting. As it's determined by the law of Ukraine On the National Bank of Ukraine and the Monetary Policy Guidelines, given the requirements of Article 6 of the NBU Law, monetary policy

\footnotetext{
${ }^{1}$ Doctor of Philosophy in Economics, Assistant Professor. Vice-Head, Docent of Department of Digital Economy and International Economic Relations, Zhytomyr Polytechnic State University, Ukraine. Contact e-mail: vitaliybondachuk@ukr.net

${ }^{2}$ Doctor of Philosophy in Economics, Assistant Professor. Docent of Department of Digital Economy and International Economic Relations, Zhytomyr Polytechnic State University, Ukraine. Contact e-mail: bjv@ukr.net

${ }^{3}$ Doctor of Philosophy in Economics, Assistant Professor. Vice-Head, Docent of Department of Digital Economy and International Economic Relations, Zhytomyr Polytechnic State University, Ukraine. Contact e-mail: Iyudakalen@gmail.com

${ }^{4}$ Doctor of Science in Economics, Assistant Professor. Head, Docent of Department of Digital Economy and International Economic Relations, Zhytomyr Polytechnic State University, Ukraine. Contact e-mail: kv.shymanska@gmail.com
} 
is primarily aimed at reducing inflation (in CPI terms) to a single digit rate and maintaining it at that level in the medium-term. Ukraine is not the only one country that behaves inflation targeting regime and interest rate considers as the main tool to rich this aim.

There are a lot of discussions about the most appropriate level of central banks interest rate and main variables that influence on it. For today the Taylor rule is one of the most popular rules of monetary policy. This rule has a lot of variations caused by difference in variables and conditions that influence on monetary policy goals. Another problem issue is values of inflation gap and GDP gap coefficients that determines interest rate. In classic Taylor rule these coefficients are 1.5 and 0.5 respectively, but their values may differ among countries under different conditions. These coefficients determine that for monetary policy inflation is more significant variable than GDP and interest rate is more dependent upon inflation rate than GDP growth rate. According to Taylor principle declines that one\% change inflation rate central bank should increase interest rate more than for one\%. But is this rule convenient in case of Ukraine?

\subsection{Literature review}

Woodford (2001) considered Taylor rule as theoretical model that not always takes into account empirical values of factors, for example GDP gap evaluation may be done different empirically and theoretically. Also, potential GDP is effected by wide variety of real disturbances that cannot be included into model. These issues should be considered in further researches.

Asso, Kahn and Leeson (2007) examined the impact of Taylor rule on Federal Reserve's conduct of monetary policy. They illustrated the impact of Taylor rule on macroeconomics and explain the way it has become such widely used in monetary policy regulation.

Bouchabchoub, Bendahmane, Haouriqui and Attou (2015) presented result of Forex predicting model simulation using Taylor rule. The Taylor rule was adopted to European and American Forex Market by combining Hall-Taylor equation and Taylor rule. Given model have been used to examine the impact of inflation shock on interest rate.

Gerlach-Kristen (2003) considered using Taylor rule on Euro area data and presented the result of including nonstationary data into model. Also, she considered significant role of consumers' perception of long term inflation rate in determining long term interest rate.

Razzak (2001) examined the McCallum modified monetary policy rule and the Taylor rule for conducting monetary policy. The result of model-evaluation of these two rules is that they are co-integrated and provide reliable tool for interest rate evaluation.

McGough, Rudebusch and Williams (2004) considered Taylor rule as tool to determine short run interest rate under conditions or its zero value. They found that Taylor rule policy can be used for long run in a standard New Keynesian model.

Backus, Gavazzoni, Telmer and Zin (2013) represented monetary policy of different countries as domestic and foreign Taylor rules. They have conducted different specifications of Taylor rule to explain uncovered interest rate parity puzzle. It's evidence of that Taylor rule may be applied for various purposes of monetary policy and monetary regulation.

Amato (2005) examined the nature and role of interest rate for development and conducting monetary policy. According to given results interest rate may be used as efficient tool of monetary policy, but it has some drawback - uncertainty of input parameters and whether interest rate can be reliable indicator for policy-makers. 
Orphanides (2002) described historic overview of monetary policy in United States, including period of Taylor rule use. Author emphasized that Taylor rule provide the tool for efficient monetary policy but there is no one variance of this rule. Under different conditions classic Taylor rule may be transformed to provide the best explanatory features of the model for decision-making.

Svensson (2003) discussioned using judgments in monetary policy against monetary rules and concluded that implementation judgments into monetary rules allow to increase robustness of obtained data.

Carlstrom, Fuerst (2002) described use of Taylor rule under conditions of neutral-rate hypothesis. Authors demonstrated that in a neutral-rate hypothesis model necessary and sufficient condition for real determinacy is for the corresponding flexible-price economy to have both real and nominal determinacy.

Sims (2001) described how the data on inflation gap and GDP gap fits the Taylor rule and investigates the validity of the assumption that there has been clear improvement in monetary policy.

\section{Methodology}

The research had been made by team of scientists according to linear regression methodology. Data analysis had been made on the basis of the official data of National Bank of Ukraine, State Statistics Service of Ukraine, from Monetary Policy Guidelines and the materials of the seminar for lecturers of Ukrainian institutions of higher education "Decision-making in monetary policy in National bank of Ukraine".

The first step was gathering initial data. All of the variables were extracted from official data bases. Potential GDP was generated with Hodrick-Prescott filter. Time series data set consist of 46 observations.

The second step was evaluating coefficients of parameters of Taylor rule. It was made using linear regression (OLS). The purpose of this step is to evaluate model accuracy for the case of Ukraine.

The third step was evaluating parameters for inflation gap and GDP gap. These parameters are significant for practical implication in central banks` monetary policy.

The last step was testing observations for structural breaks. We choose the third quarter of 2011 as a period for the test, because it is the middle of time series.

All calculations have been done in Microsoft Excel and R software.

\section{Results}

\subsection{Taylor rule in monetary policy}

Any central bank is in charge of development and conduction monetary policy in its country. But there are a lot of approaches to purposes and methods of monetary policy that central bank should carry out. There is a wide range of types of monetary policy: inflation targeting, price level targeting, money supply targeting, nominal gross domestic product targeting, fixed exchange rate targeting.

For the recent decades, the most common monetary policy is based on inflation targeting. Stable and low inflation rate is main goal of conducting this policy, but to reach this aim different tools can be used, like money supply regulation or interest rate regulation.

Both money supply regulation and interest rate regulation represents monetary policy rules. In general, monetary policy rules allow to monetary policy become more precious, transparent and consistent. Rules, like any other econometrics model, helps policy-makers to cope with statistics data and to develop some objects to 
deal with uncertainty of economic environment. Monetary policy rules point to quantitate goals of policymakers, point to necessity to conduct expansionary or contractionary monetary policy.

Pursuant to the Article 99 of the Constitution of Ukraine, providing stability of national currency is the main function of the National Bank of Ukraine. The National Bank of Ukraine promotes to achieve steady pace of economic growth and support economic policy of the Cabinet of Ministers of Ukraine in case if it's policy does not prevent to reach the goal of price and financial stability.

Maintaining support of purchasing power of national currency providing thanks to maintaining in middle-run low and stable inflation rate in terms of consumption price index. To achieve settled goals National Bank of Ukraine, adhere to the principles of conducting monetary policy: priority to achieve and maintain price stability; maintaining floating currency rate; prospective approach in decision-making that based on macroeconomic basis and provide economic growth.

National Bank of Ukraine uses interest rate to conduct monetary policy and to provide inflation targeting. Making the decision on interest rate National Bank of Ukraine orients on both target and current inflation rate. In case if predictive value of inflation is higher than target value, National Bank of Ukraine conducts contractionary monetary policy to achieve target inflation rate. And contrary, if predictive value of inflation is lower than target value, National Bank of Ukraine conducts expansionary monetary policy. Thus, in middle-run current inflation have to come back to target rate.

Most central banks use Taylor rule to reach their goals of target inflation rate, that was established in 1993 by prof. John Taylor, Stanford University. Classic Taylor rule has the next form

$$
i_{t}=\pi_{t}+r_{t}+\beta_{\pi}\left(\pi_{t}-\pi_{t}^{*}\right)+\beta_{y}\left(y_{t}-y_{t}{ }^{-}\right)
$$

Where: $i_{t}$ - short-run nominal interest rate, $\pi_{t}$-inflation rate (in terms of consumption price index), $r_{t}-$ neutral interest rate, $\pi_{t}{ }^{*}-$ target inflation rate, $y_{t}-\log$ real GDP, $y_{t}^{-}$- potential GDP, $\beta_{\pi}$-coefficient of inflation gap, $\beta_{t}$ - coefficient of GDP gap.

Coefficients of equation are selected including few conditions:

- acceptable amplitude of GDP rate oscillation, inflation rate and interest rate in using Taylor rule;

- elimination of exceed of repeated cycle of values floating, when after initial shock of using monetary tools GDP, inflation rate and interest rate changing with higher amplitude;

- conformity of speed and time of current inflation rate moves to target rate according to policy-maker`s plan.

The value of inflation gap coefficient usually is more than 1 and well known as "Taylor principle". It means that central bank reacts more intensive on price change than GDP change. Taylor rule includes GDP gap for two reasons. The first one is that GDP gap rate is an indicator of future inflation rate and the second one is that GDP gap allows to distinguish consumption shock and price shock. For example, negative value of consumption shock causes decreases of inflation rate. And if price shock takes place GDP and price index changing in opposite directions. Under conditions of price shock policy-makers have to choose between increasing economic growth or decreasing inflation.

The amplitude of GDP rate oscillation increases with increase of GDP gap coefficient, so Taylor rule became more sensitive to the consumption shock. In case if GDP gap coefficient is to high, it leads to the interest rate reacts not to inflation but to GDP floating, so the inflation ignores. Thus, the GDP gap coefficient usually is less then 1. 
Taylor rule can be modified in different ways. It may include lagged interest rate $\left(i_{t-1}\right)$ that makes the rule more adaptive. If inflation rate $\left(\pi_{t}\right)$ will be replaced on target inflation rate $\left(\pi_{t}^{*}\right)$ this rule become a predictable rule.

\subsection{Data}

We analyzed monetary policy using Taylor rule in case of Ukraine to determine optimal interest rate to promote price stability. We use classical Taylor rule represented by equation (1). Current inflation data have been taken from the official website of National Bank of Ukraine. Data on target inflation rate have been taken from Monetary Policy Guidelines for 2017 and medium term. Data on neutral interest rate for Ukraine was provided by the materials of the seminar for lecturers of Ukrainian institutions of higher education "Decision-making in monetary policy in National bank of Ukraine" (2016). Real GDP data have been taken from the official website of State Statistics Service of Ukraine. GDP gap have been evaluated as the difference between quarter GDP and it's trend, generated by Hodrick-Prescott filter. The plots of parameters included into Taylor rule represented on Figure 1. We used 46 observations, consisted of quarters data for the period 1 quarter $2006-2$ quarter 2017.

The basis of our investigation is modified Taylor rule where interest rate is a function of interest rate in previous period, inflation rate, neutral interest rate, inflation gap and GDP gap represented by equation (2).

$$
i_{t}=i_{t-1}+\pi_{t}+r_{t}+\beta_{\pi}\left(\pi_{t}-\pi_{t}^{*}\right)+\beta_{y}\left(y_{t}-y_{t}{ }^{-}\right)
$$

Where: it - short-run nominal interest rate, it-1 - interest rate in previous period, $\pi \mathrm{t}-$ inflation rate (in terms of consumption price index), rt - neutral interest rate, $\pi \mathrm{t}^{*}$ - target inflation rate, yt - log real GDP, yt- - potential GDP, $\beta \pi$ - coefficient of inflation gap, $\beta y$ - coefficient of GDP gap.

Parameters included in Taylor rule in case of Ukraine are represented in Figure 1.

Figure 1

Parameters included in Taylor rule (case of Ukraine)
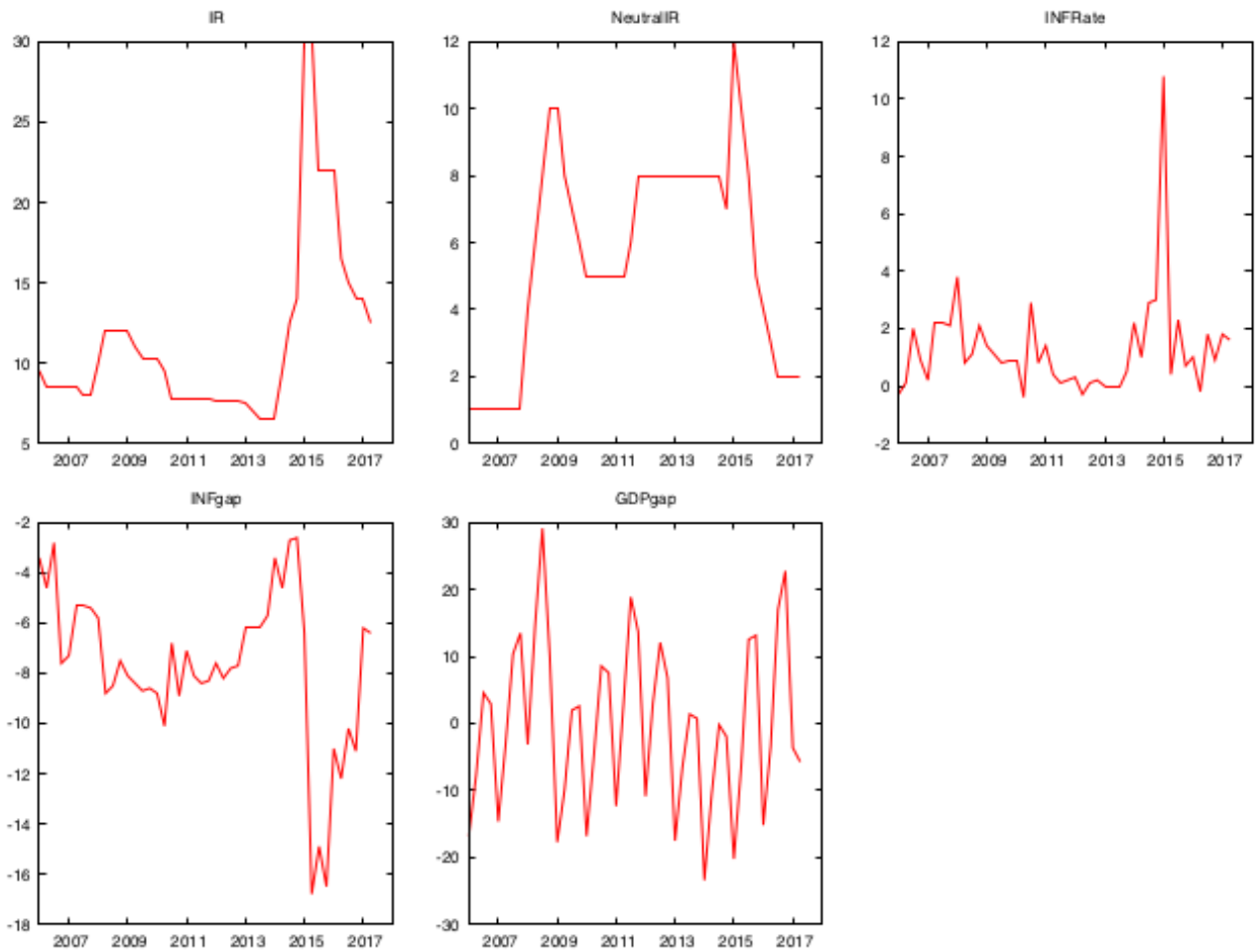

Source: Authors calculations 


\subsection{Estimation}

First of all, we analyzed factors influenced interest rate. The results are given at Table 1 . We have Durbin-Watson coefficient 2,111051 that is close to 2 and rho coefficient $-0,081944$ that is close to zero, that seems that variables has no autocorrelation. R-squared is 0,912415 that seams about close relationship between interest rate and variables influenced on it. Results are shown in Table 1. Table 1 shows that the most significant influence on interest rate makes inflation rate and interest rate in previous period. It means that $1 \%$ change of consumption prices and interest rate in previous period increases interest rate by 1,28 and $0,71 \%$ respectively. Instead $1 \%$ change in GDP gap causes only $0,04 \%$ change in interest rate. This evidenced that National Bank of Ukraine conducts monetary policy based on inflation targeting and in decision-making policy-makers orients on inflation rate. GDP growth is out of purposes policy-makers and GDP gap coefficient is only -0,04.

Table 1

Evaluation of Taylor rule for Ukraine

\begin{tabular}{|l|c|c|c|c|}
\hline \multicolumn{1}{|c|}{ Variables } & Coefficient & Std. Error & t-ratio & p-value \\
\hline const & -1.12288 & 0.841288 & -1.335 & 0.1895 \\
\hline$i_{t-1}$ & 0.710028 & 0.0834397 & 8.509 & $<0.0001^{* * *}$ \\
\hline$\pi_{t}$ & 1.28334 & 0.176309 & 7.279 & $<0.0001^{* * *}$ \\
\hline$r_{t}$ & 0.134900 & 0.0922738 & 1.462 & 0.1516 \\
\hline$\pi_{t}-\pi_{t}^{*}$ & -0.270038 & 0.160685 & -1.681 & 0.1006 \\
\hline$y_{t}-y_{t}^{-}$ & -0.0437524 & 0.0231696 & -1.888 & $0.0662^{*}$ \\
\hline R-squared & 0.912415 & & & \\
\hline rho & -0.081944 & & & \\
\hline $\begin{array}{l}\text { Durbin- } \\
\text { Watson }\end{array}$ & 2.111051 & & & \\
\hline
\end{tabular}

Source: Authors calculations

Also, interest rate is significantly dependent from previous interest rate value that evidenced that current interest rate very slowly changing relative to the target interest rate.

The next step was to evaluate $\beta \pi$ (coefficient of inflation gap) and $\beta y$ (coefficient of GDP gap). It has been done using nonlinear list squares. The results are given in Table 2.

Table 2

Evaluation of coefficients inflation gap and GDP gap

\begin{tabular}{|l|c|c|c|c|}
\hline \multicolumn{1}{|c|}{ Parameter } & Value & Std. Error & t-ratio & p-value \\
\hline beta1 & 0,811678 & 0,0612993 & 13,24 & $<0,0001$ \\
\hline beta2 & 0,0422378 & 0,0416253 & 1,015 & 0,3158 \\
\hline
\end{tabular}

Source: Authors calculations

Table 2 shows that received coefficients are significantly different from coefficients in original Taylor rule. Thus, Taylor rules ' coefficient of inflation gap is 1,5 and coefficient of GDP gap is 0,5, but estimated coefficients in case of Ukraine are 0,8 and 0,04 respectively. Given results confirmed our previous result that National Bank of Ukraine uses inflation rate as major target of monetary policy conducting but not GDP growth.

To defined whether National Bank of Ukraine uses the same policy through the whole investigated period we used Chow test to defined structural break (Table 3). Chow test showed that model has no structural break. This is confirmed by $p$-value 0,0253 that is less than 0,05 . 
Table 3

Chou test for structural break

\begin{tabular}{|c|c|c|c|c|}
\hline Variables & Coefficient & Std. Error & t-ratio & $p$-value \\
\hline const & 1,99839 & 4,24247 & 0,4710 & 0,6406 \\
\hline$i_{t-1}$ & 0,738630 & 0,387425 & 1,907 & $0,0651^{*}$ \\
\hline$\pi_{t}$ & 0,0737386 & 0,431621 & 0,1708 & 0,8654 \\
\hline$r_{t}$ & 0,105685 & 0,248812 & 0,4248 & 0,6737 \\
\hline$\pi_{t}-\pi_{t}^{*}$ & 0,0190970 & 0,289667 & 0,06593 & 0,9478 \\
\hline$y_{t}-y_{t}^{-}$ & 0,00391518 & 0,0302063 & 0,1296 & 0,8976 \\
\hline splitdum & $-3,30331$ & 4,41210 & $-0,7487$ & 0,4592 \\
\hline sd_ $i_{t-1}$ & $-0,181053$ & 0,400572 & $-0,4520$ & 0,6541 \\
\hline $\mathrm{sd} \_\pi_{t}$ & 1,52466 & 0,470609 & 3,240 & $0,0027^{* * *}$ \\
\hline $\mathrm{sd} \_r_{t}$ & $-0,0253304$ & 0,286919 & $-0,08828$ & 0,9302 \\
\hline $\mathrm{sd} \_\pi_{t}-\pi_{t}^{*}$ & $-0,575776$ & 0,350892 & $-1,641$ & 0,1100 \\
\hline $\mathrm{sd}_{-} y_{t}-y_{t}^{-}$ & $-0,0668378$ & 0,0442799 & $-1,509$ & 0,1404 \\
\hline \multicolumn{5}{|c|}{$\begin{array}{l}\text { Chow test for structural break at observation } 2011: 3 \\
\qquad F(6,34)=2.80023 \text { with p-value } 0.0253\end{array}$} \\
\hline
\end{tabular}

Source: Authors calculations

\section{Conclusions}

We have conducted Taylor rule to evaluate the value of interest rate in Ukraine and to determine inflation gap and GDP gap coefficients. Time series data consisted of 46 observations for the period 1 quarter $2006-2$ quarter 2017. Obtained results showed that the most significant influence on interest rate makes inflation rate and interest rate in previous period. It has been found that $1 \%$ change of consumption prices and interest rate in previous period increases interest rate by 1,28 and $0,71 \%$ respectively. Instead $1 \%$ change in GDP gap causes only $0,04 \%$ change in interest rate. Also received coefficient of inflation gap and coefficient of GDP gap are significantly differing from values of these coefficients in classic Taylor rule.

Chow test showed that investigated model has no structural break through the period 2006-2017. This is confirmed by $p$-value 0,0253 that is less than 0,05 and evidenced that there were no structural breaks that influenced on monetary policy.

Obtained results seems that $1 \%$ change of inflation gap provoke National Bank of Ukraine to increase interest rate by $0,8 \%$. It means that National Bank of Ukraine conducting monetary policy that is not oriented on inflation targeting, but that is not correct. The case of monetary policy in Ukraine is that up to 2014 National Bank of Ukraine had no inflation targeting. The main goal of monetary policy was price stability, but all efforts of central bank were directed on reducing of inflation and fixing of price floating consequences. Thus, obtained results as for coefficients of Taylor rule are not useful. After inflation targeting has been launched in 2014 there is insufficient data set to determine inflation gap and GDP gap coefficients.

\section{Bibliographic references}

Amato, J. (2005). The Role of the Natural Rate of Interest in Monetary Policy. Cesifo Economic Studies, 51(4), 729-755. doi: 10.1093/cesifo/51.4.729

Backus, D., Zin, S., Gavazzoni, F., \& Telmer, C. (2010). Monetary Policy and the Uncovered Interest Rate Parity Puzzle. SSRN Electronic Journal. doi: 10.2139/ssrn.1634825

Bouchabchoub, T., Bendahmane, A., Haouriqui, A., \& Attou, N. (2015). Interest Rate Prediction with Taylor Rule. International Journal Of Trade, Economics And Finance, 6(1), 58-61. doi: 10.7763/ijtef.2015.v6.443 
Carlstrom, C., \& Fuerst, T. (2002). Taylor Rules in a Model that Satisfies the Natural-Rate Hypothesis. American Economic Review, 92(2), 79-84. doi: 10.1257/000282802320189041

Gerlach-Kristen, P. (2003). Interest Rate Reaction Functions and the Taylor Rule in the Euro Area. Retrieved from https://ssrn.com/abstract=457526

Kahn, G., Asso, P., \& Leeson, R. (2007). The Taylor Rule and the Transformation of Monetary Policy. SSRN Electronic Journal. doi: 10.2139/ssrn.1088466

McGough, B., Rudebusch, G., \& Williams, J. (2004). Using a Long-Term Interest Rate as the Monetary Policy Instrument. SSRN Electronic Journal. doi: 10.2139/ssrn.650904

Macroeconomic parameters. (2017). Retrieved from https://bank.gov.ua/control/uk/publish/article?art_id=23487024\&cat_id=57896

Monetary policy guidelines for 2017 and medium term. (2017). Retrieved from https://bank.gov.ua/doccatalog/document?id=41652890

Nikolaychuk, S. (2016). Decision-making in monetary policy in National bank of Ukraine. Retrieved from https://bank.gov.ua/doccatalog/document?id=39476461

Orphanides, A. (2003). Historical monetary policy analysis and the Taylor rule. Journal Of Monetary Economics, 50(5), 983-1022. doi: 10.1016/s0304-3932(03)00065-5

Razzak, W. (2002). Is the Taylor Rule Really Different from the McCallum Rule?. SSRN Electronic Journal. doi: $10.2139 /$ ssrn. 320288

Sims, C. (2001). A Review of Monetary Policy Rules. Journal Of Economic Literature, 39(2), 562-566. doi: 10.1257/jel.39.2.562

State Statistics Service of Ukraine. (2018). Retrieved from http://www.ukrstat.gov.ua

Svensson, L. (2003). What Is Wrong with Taylor Rules? Using Judgment in Monetary Policy through Targeting Rules. Journal Of Economic Literature, 41(2), 426-477. doi: 10.1257/002205103765762734

Woodford, M. (2001). The Taylor Rule and Optimal Monetary Policy. American Economic Review, 91(2), 232237. doi: 10.1257/aer.91.2.232 